\title{
L-Tryptophan and Related Compounds Induce Larval Settlement of the Barnacle Balanus amphitrite Darwin
}

\author{
Kazumi Kon-ya, ${ }^{\dagger}$ Wataru Miki, ${ }^{\dagger \dagger}$ and Mamoru Endo \\ Marine Biotechnology Institute (MBI) Shimizu Laboratories, \\ 1900, Sodeshi, Shimizu, Shizuoka 424, Japan \\ (Received September 5, 1994)
}

\begin{abstract}
Effects of L-tryptophan and related compounds on larval settlement of barnacle Balanus amphitrite Darwin were examined. The settlement rate of young cyprids increased in proportion to L-tryptophan concentration $\left(1.8 \times 10^{-5} \mathrm{M}\right.$ to $\left.5.6 \times 10^{-4} \mathrm{M}\right)$. The inducing effect of serotonin (5-hydroxytryptamine; 5-HT) on larval settlement was similar to that of L-tryptophan at the concentration range of $3.4 \times 10^{-7} \mathrm{M}$ to $1.1 \times 10^{-5} \mathrm{M}$. When 5-HT was applied to old cyprids, however, no inducing effect of larval settlement was observed. On the other hand, reserpin, a depleting agent of neuroactive amines such as 5-HT in mammals, showed inhibitory activity on settlement of old cyprids at the concentration of $10^{-7} \mathrm{M}$.
\end{abstract}

Key words: barnacle, cypris larvae, Balanus amphitrite, settlement inducer, L-tryptophan, 5-HT

It has been reported that settlement and metamorphosis of marine invertebrate larvae are induced by the larval recognition of biochemical signals from their living circumferences. ${ }^{1-3)}$ Further, it has been referred that endogenous factors such as sensory receptors, catalytic factors and metamorphic factors exist in the marine invertebrate larvae. ${ }^{4-9}$ Larvae of the red abalone Haliotis rufescens have been found to settle and metamorphose in response of $\gamma$ aminobutyric acid (GABA) ${ }^{4,5)}$ GABA is successfully and routinely used for abalone aquaculture now. It was reported that larvae of the giant Pacific oyster Crassostrea gigas and pediveliger larvae of the blue mussel Mytilus edulis settled in response to L-DOPA (L-3,4-dihydroxyphenylalanine).$^{7-10)}$

Barnacles are one of the most troublesome fouling kinds of organisms. It has been reported that arthropodins which were proteins obtained from adult barnacles, ${ }^{11,12)}$ some bacterial films, ${ }^{13)}$ and some synthetic short-chained peptides ${ }^{14)}$ induced larval settlement. A few studies concerning the effects of ions and several amines on larval settlement were also reported. ${ }^{15)}$ However, the influences of these substances on their settlement still remain unknown.

In the present study, we examined the effect of an amino acid, L-tryptophan, and related compounds on larval settlement of the barnacle Balanus amphitrite, and discussed the possible roles as settlement inducers.

\section{Materials and Methods}

\section{Barnacle Cyprids}

Hatched nauplii of $B$. amphitrite were obtained from reared adults which had been fed with Artemia salina in the laboratory at $23^{\circ} \mathrm{C}$. Cyprids were reared from the first stage of nauplius larvae, which had been fed with Chaetoceros calcitrans at $23^{\circ} \mathrm{C}$. The day of metamorpho- sis to cyprid was defined as day 0 . The settlement assay was performed using either young cyprids at 0-day-old or old cyprids at 7 -day-old (kept at $5^{\circ} \mathrm{C}$ ). Seawater (salinity; 32) was filtered through $100 \mu \mathrm{m}$ mesh for rearing adults barnacles, and filtered through $0.45 \mu \mathrm{m}$ mesh for rearing larvae.

\section{Settlement Assay}

Each test sample was dissolved or suspended in $0.1 \mathrm{ml}$ of methanol or methanol-water (1:1), coated on a polystyrene Petri dish ( $35 \mathrm{~mm}$ in diameter; Petorei $35 \mathrm{M} / \mathrm{M}$, Terumo Co., Ltd.) at $23^{\circ} \mathrm{C}$, and dried in air. Five $\mathrm{ml}$ of seawater filtered through $0.45 \mu \mathrm{m}$ mesh was added into each Petri dish. Ten cyprids were inoculated into each Petri dish. After incubation at $23^{\circ} \mathrm{C}$ for $24 \mathrm{~h}$ in the dark, the number of cyprids which settled on the inner surface of each Petri dish was counted. Three Petri dishes were prepared for one test sample and an average value was obtained simply by adding all individual values and dividing the sum by three. Correlation coefficients for response vs. concentration were estimated by the least squares method.

\section{Results and Discussion}

The effect of L-tryptophan on larval settlement was examined at the concentrations of $1.8 \times 10^{-5}, 3.5 \times 10^{-5}$, $7.0 \times 10^{-5}, 1.4 \times 10^{-4}, 2.8 \times 10^{-4}$ and $5.6 \times 10^{-4} \mathrm{M}$ using young cyprids. Branscomb and Rittschof ${ }^{16)}$ reported that young cyprids usually showed lower settlement rate. As shown in Fig. 1, when no inducers were added, the settlement rate of young cyprids at the control was found to be $7 \%$. The settlement rate of cypris larvae increased in proportion to L-tryptophan concentration. Since L-tryptophan may be metabolized within cypris larvae, the effects of the metabolites such as 5-hydroxy-L-tryptophan, tryptamine and serotonin (5-HT) on larval settlement were exam-

\footnotetext{
${ }^{\dagger}$ Ihara Chemical Ind. Co., Ltd., 2256, Nakanogo, Fujikawa, Ihara, Shizuoka 421-33, Japan.

" Suntory Research Center, 1-1-1, Wakayamadai, Shimamoto, Mishima, Osaka 618, Japan.
} 


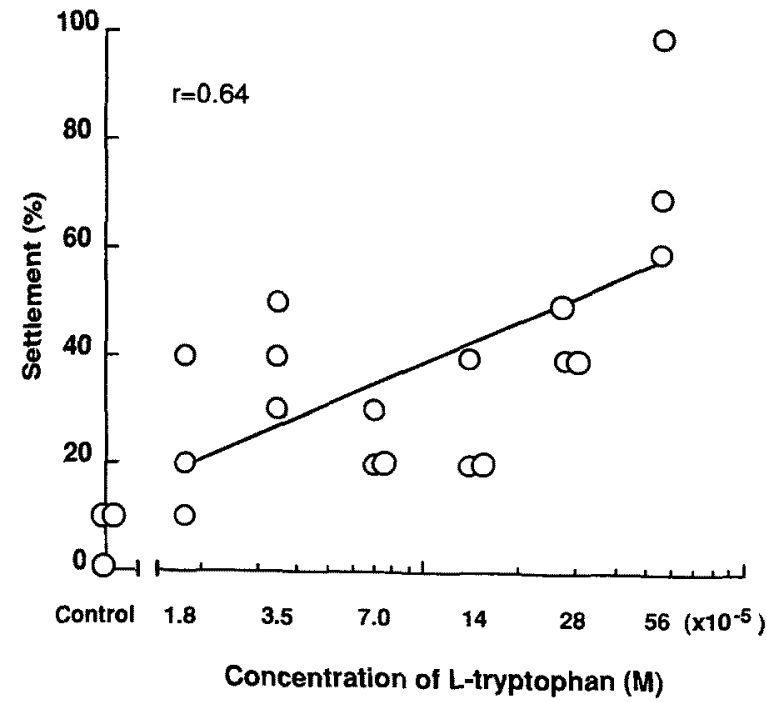

Fig. 1. Effect of L-tryptophan on the settlement of young cyprids (day 0) of Balanus amphitrite.

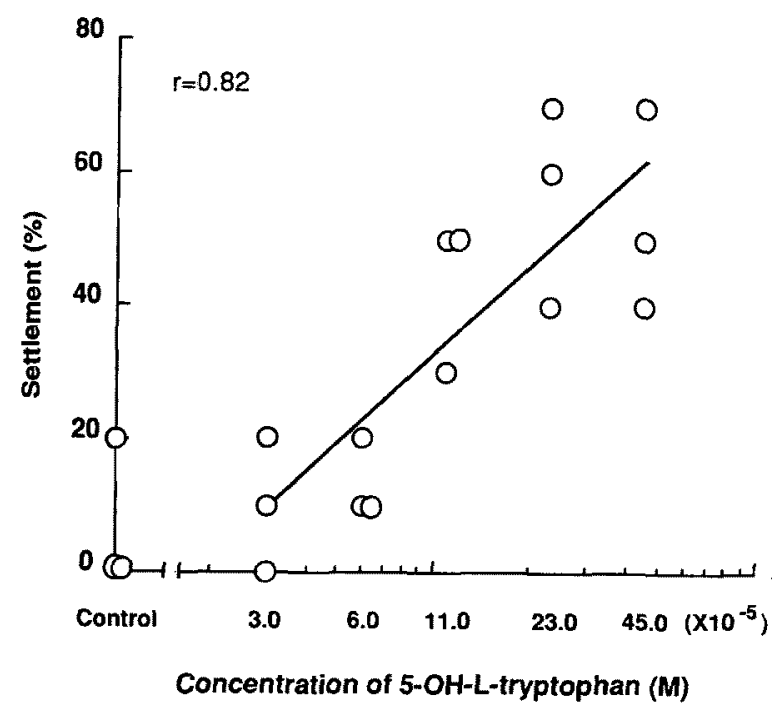

Fig. 2. Effect of 5-hydroxy-L-tryptophan on the settlement of young cyprids (day 0) of Balanus amphitrite.

ined using young cyprids. The inducing effect of 5hydroxy-L-tryptophan on larval settlement was similar to that of L-tryptophan (Fig. 2). Tryptamine also showed inducing effect on larval settlement behaviors. However, at the higher concentrations $\left(7.9 \times 10^{-5} \mathrm{M}\right.$ and over), some larvae metamorphosed without settlement. At the highest concentration $\left(6.3 \times 10^{-4} \mathrm{M}\right)$, most cyprids failed to settle and metamorphose. The effect of tryptamine, including the values of individuals which metamorphosed without settlement, was plotted in Fig. 3. In the case of the giant Pacific oyster C. gigas, Coon and Bonar ${ }^{8)}$ reported that $\mathrm{L}$ DOPA induced metamorphosis of larvae at the maximum rate at $2.5 \times 10^{-5} \mathrm{M}$. However, concentration of L-DOPA above $10^{-4} \mathrm{M}$ caused high mortality against the oyster larvae. Tryptamine might also have toxic effects on the cypris larvae of the barnacle at higher concentrations. 5-HT

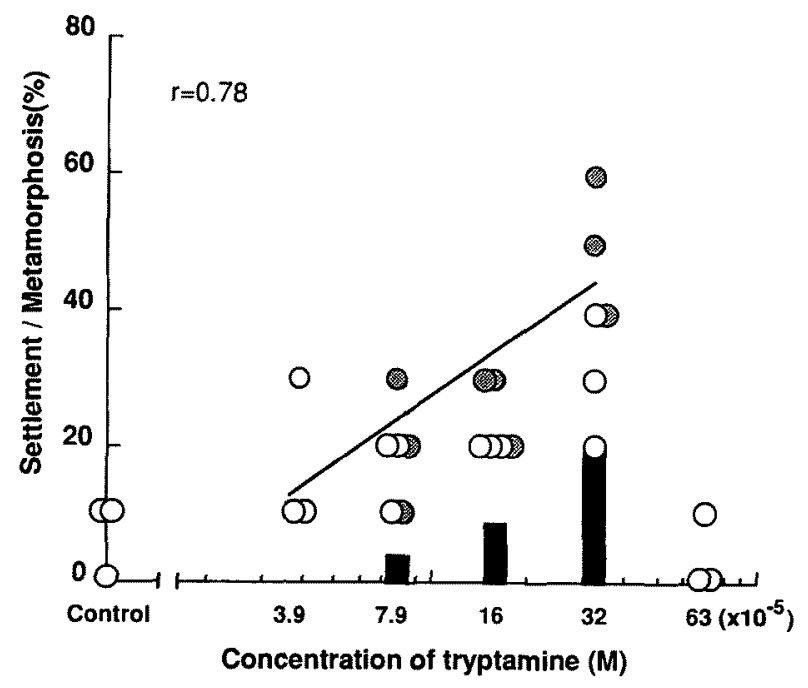

Fig. 3. Effect of tryptamine on the settlement of young cyprids (day 0 ) of Balanus amphitrite.

$O$ : Settled and metamorphosed, a : Average of metamorphosed cyprids without settlement, 1 : Metamorphosed cyprids $\left(\mathrm{O}^{+} \bullet\right)$. Correlation coefficient was estimated at concentration range of $3.9 \times 10^{-5} \mathrm{M}$ to $3.2 \times 10^{-4} \mathrm{M}$.

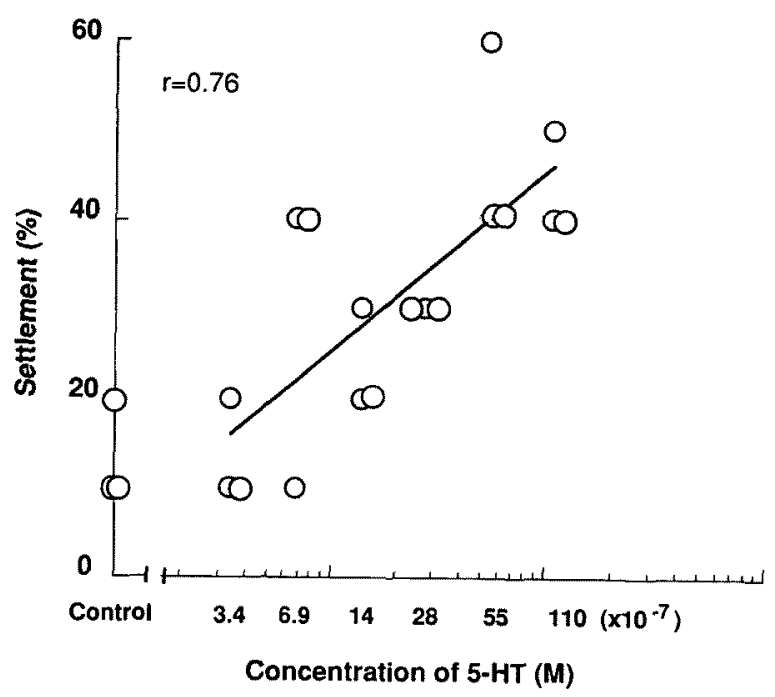

Fig. 4. Effect of 5-HT on the settlement of young cyprids (day 0) of Balanus amphitrite.

(serotonin creatinine sulfate) was examined at the concentrations of $3.4 \times 10^{-7}, 6.8 \times 10^{-7}, 1.4 \times 10^{-6}, 2.8 \times 10^{-6}$, $5.5 \times 10^{-6}$ and $1.1 \times 10^{-5} \mathrm{M}$ using young cyprids. As shown in Fig. 4, the settlement rate of cypris larvae increased in proportion to 5-HT concentration.

Since it is reported that the settlement rate of cypris larvae spontaneously increased according to their age within a given period ${ }^{16,17)}$ the effect of 5-HT on larval settlement was examined using old cyprids. As shown in Fig. 5, the settlement rate of old cyprids was $57 \%$ even when no inducers were added (compared with Fig. 1), and no inducing effect of 5-HT on larval settlement was observed.

We hypothesized that the role of these compounds might be endogenous factors or their mimics on larval set- 


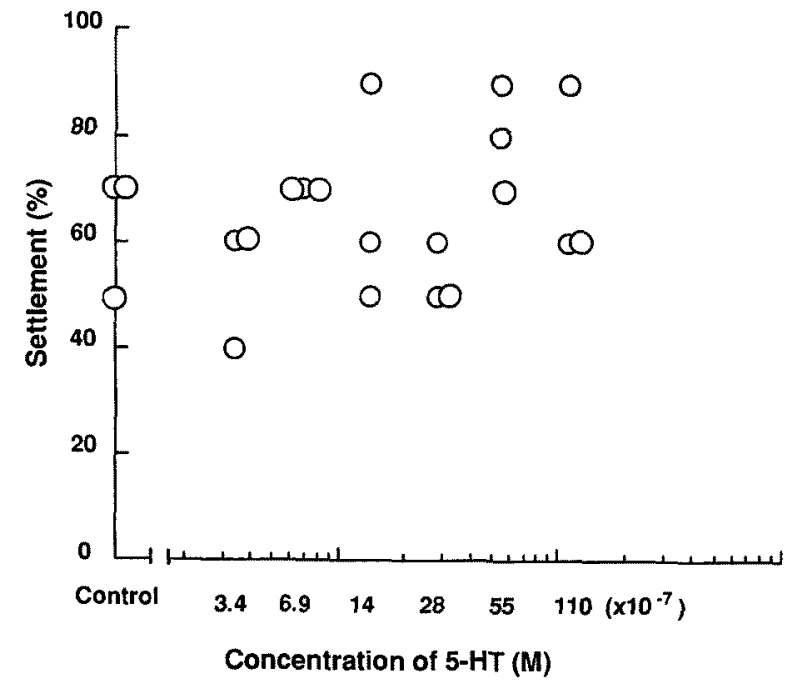

Fig. 5. Effect of 5-HT on the settlement of old cyprids (day 7) of Balanus amphitrite.

tlement in a cyprid. Furthermore, we considered that cypris larvae might gradually accumulate the amine concentration up to the level enough to reveal spontaneous settlement ability during the storage for 7 days at $5^{\circ} \mathrm{C}$. Therefore, the effects of the compounds known as 5-HT inhibitors in mammals were examined using old cyprids. Reserpin and cyproheptadine (hydrochloride) were examined at the concentration range of $10^{-10}, 10^{-9}, 10^{-8}, 10^{-7}$ and $10^{-6} \mathrm{M}$. As shown in Fig. 6, the settlement rate of old cyprids decreased in proportion to reserpin concentration. At the concentration of $10^{-7} \mathrm{M}$ reserpin, all cyprids failed to settle, even though all cypris larvae survived. Cyproheptadine also showed inhibiting effect on larval settlement at the $10^{-6} \mathrm{M}$ concentration (Fig. 6). Reserpin is known as a depleting agent of 5-HT, a neuroactive amine in human brain and other tissues of higher animals, ${ }^{18)}$ and cyproheptadine is a 5-HT receptor antagonist. ${ }^{19)}$ Based on this fact, it is considered that reserpin could be 5-HT depleting agent in cypris larvae, and cyprids might possess a certain 5-HT receptors. These results also indicate that some 5-HT inhibitors $^{20)}$ may show antifouling activity of $B$. amphitrite cyprids.*

The possible mechanisms on larval settlement and metamorphosis in marine invertebrate larvae were illustrated. Chia ${ }^{6}$ described the mechanism as follows: Once a larva becomes competent, it must have acquired a chemical substance (metamorphic factor); this factor is masked, and it cannot exert its effect unless it is unmasked; the mask itself may undergo a natural decay so that the "aged" larvae will metamorphose even though the environmental cue are not available; the mask can be easily destroyed by another factor (catalytic factor) which is produced by the larva when it is stimulated by the environmental cues. In our test using B. amphitrite cyprids, compounds used have a possibility of potent substance as meta-

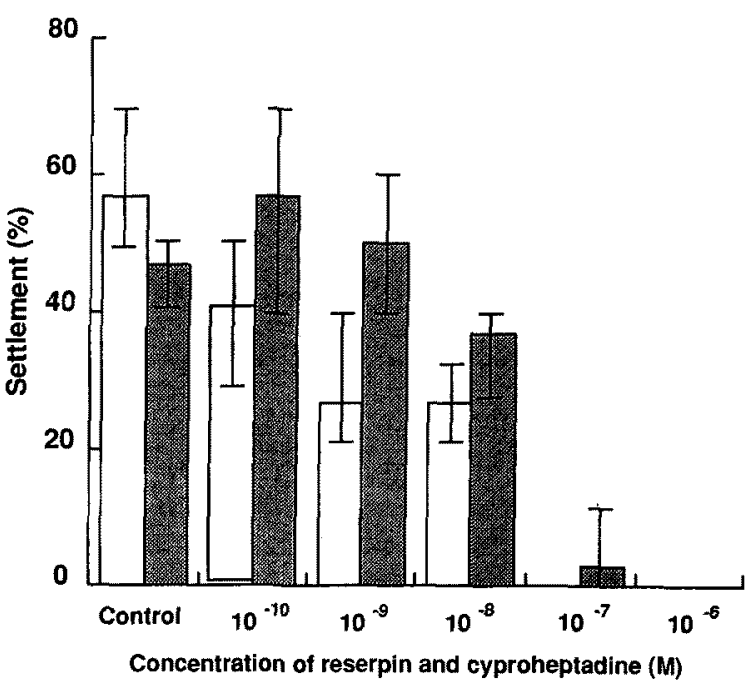

Fig. 6. Effects of reserpin and cyproheptadine on the settlement of old cyprids (day 7) of Balanus amphitrite.

$\square$ : Reserpin, : Cypropheptadine. Error bars denote min$\max$.

morphic factor and/or its precursor mentioned above by Chia."

The endogenous inducing compound on larval settlement and uptake mechanisms of the compounds tested in this study into the some organs of cypris larva are still left unidentified. It becomes clear, however, that L-tryptophan and related compounds have inducing effects on settlement of young cyprids, and reserpin and cyproheptadine have inhibiting effects on settlement of old cyprids of $B$. amphitrite. Moreover, L-tryptophan and the related compounds may play an important role as trigger on larval settlement and metamorphosis of the barnacle $B$. amphitrite.

Acknowledgments We wish to express our thanks to Professor S. Miyachi of MBI for his critical discussions. This work was performed as a part of the Industrial Science and Technology Frontier Program supported by the New Energy and Industrial Technology Development Organization of Japan.

\section{References}

1) D. J. Crisp: Factors influencing the settlement of marine invertebrate larvae, in "Chemoreception in Marine Organisms" (ed. by P. T. Grant and A. M. Mackie), Academic Press, New York, 1974, pp. 177-265.

2) D. J. Crisp: Overview of research on marine invertebrate larvae 1940-1980, in "Marine Biodeterioration; An Interdisciplinary Study" (ed. by J. D. Costlow, and R. C. Tipper), Naval Institute Press, Annapolis, Maryland, 1984, pp. 103-126.

3) A. N. C. Morse and D. E. Morse: Recruitment and metamorphosis of Haliotis larvae induced by molecules uniquely available at the surfaces of crustone red algae. J. Exp. Mar. Biol. Ecol., 75, 191215 (1984).

4) D. E. Morse, N. Hooker, H. Duncan, and L. Jensen: $y$-Aminobutyric acid, a neurotransmitter, induces planktonic abalone larvae to

\footnotetext{
* We have isolated 2,5,6-tribromo-1-methylgramine (TBG) from the marine bryozoan Zoobotryon pellucidum as an antifouling substance. ${ }^{21)}$ Its minimum inhibitory concentration on larval settlement of $B$. amphitrite was $7.5 \times 10^{-8} \mathrm{M}$, where mortality effect was very slight. This effect against the cyprids was seemed to be similar to those of 5-HT inhibitors such as reserpin and cyproheptadine. Settimo et al.20) reported that bromo-substituted gramines such as 2,6-dibromo-1-methylgramine have an anti-5-HT activity in rat stomach using cyproheptadine as a positive control. Thus, TBG may have an anti-5-HT activity in cypris larvae.
} 
settle and begin metamorphosis. Science, 204, 407-410 (1979).

5) D. E. Morse: Neurotransmitter-mimetic inducers of larval settlement and metamorphosis. Bull. Mar. Sci., 37, 694-706 (1985).

6) F. S. Chia: Perspectives: Settlement and metamorphosis of marine invertebrate larvae, in "Settlement and Metamorphosis of Marine Invertebrate Larvae" (ed. by F. S. Chia and M. E. Rice), Elsevier Press, New York, 1977, pp. 283-285.

7) R.M. Weiner, A. M. Segall, and R. R. Colwell: Characterization of a marine bacterium associated with Crassostrea virginica (the Eastern oyster). Environ. Microbiol., 49, 83-90 (1985).

8) S. L. Coon and D. B. Bonar: Induction of settlement and metamorphosis of the pacific oyster, Crassostrea gigas (Thunberg), by LDOPA and catecholamines. J. Exp. Mar. Biol. Ecol., 94, 211-221 (1985).

9) K. Cooper: Model to explain the induction of settlement and metamorphosis of planktonic eyed-pediveligers of the blue mussel, Mytilus edulis L., by chemical and tactile cues. J. Shellfish Res., 2, 117 (1982).

10) K. Cooper: Potential for application of the chemical DOPA to commercial bivalve settling systems. J. Shellfish Res., 3, 110-111 (1983)

11) D. J. Crisp and P. S. Meadows: The chemical basis of gregariousness in cirripedes. Proc. R. Soc. Lond. Ser. B, 156, 500-520 (1962).

12) V. N. Larman, P. A. Gabott, and J. East: Physico chemical properties of the settlement factor proteins from the barnacle Balanus balanoides. Com. Biochem. Physiol., 72B, 329-338 (1982).
13) J. S. Maki, D. Rittschof, J. D. Costlow, and R. Mitchell: Inhibition of attachment of larval barnacles, Balanus amphitrite, by bacterial surface films. Mar. Biol., 97, 199-206 (1988).

14) K. Tegtmeyer and D. Rittschof: Synthetic peptide analogs to barnacle settlement pheromone. Peptides, 9, 1403-1406 (1989).

15) D. Rittschof, J. Maki, R. Mitchell, and J. D. Costlow: Ion and neuropharmacological studies of barnacle settlement. Netherl. J. Sea. Res., 20, 269-275 (1986).

16) E. S. Branscomb and D. Rittschof: An investigation of low frequency sound waves as a means of inhibiting barnacle settlement. $J$. Exp. Mar. Biol. Ecol., 79, 149-154 (1984).

17) D. J. Crisp and P. S. Meadows: Adsorbed layers: the stimulus to settlement in barnacles. Proc. R. Soc. Lond. Ser. B, 158, 364-387 (1963).

18) I. Itoh: Pharmacology, Eikodo, Tokyo, 1980, pp. 144 (in Japanese).

19) H. Hidaka: Inhibitors in Modern Biology and Medicine, Kyoritsusyuppan, Tokyo, 1985, pp. 62 (in Japanese).

20) A. D. Settimo, G. Primofiore, P. L. Ferrarini, J. S. Franzone, R. Cirillo, and C. Cravanzola: Bromoderivatives of gramine, preparation and pharmacological properties. Eur. J. Med. Chem. Chim. Ther., 18, 261-267 (1983).

21) K. Kon-ya, N. Shimidzu, K. Adachi, and W. Miki: 2,5,6-Tribromo1-methylgramine, an antifouling substance from the marine bryozoan. Zoobotryon pellucidum. Fisheries Sci., 60, 773-775 (1994). 